\title{
位相マスク干渉法によるファイバブラッググレーティングを用いた 負帰還半導体光増幅器の雑音抑制効果
}

\author{
前田 佳伸 ${ }^{1,3}$, 谷本 浩一 ${ }^{1}$, 松尾 達弥 ${ }^{1}$, 高木 正和 ${ }^{2}$, 中山 秀樹 ${ }^{3}$ \\ 1近畿大学 理工学部電気電子学科 ( ₹ $577-8502$ 大阪府東大阪市小若江3-4-1) \\ 23ツタ電線 (株) († 620-0853 京都府福知山市長田野町3-17) \\ 3光トライオード (株) († 577-0817 大阪府東大阪市近江堂2-10-41)
}

\section{Noise Reduction Effect of Negative Feedback Semiconductor Optical Amplifiers Using Fiber Bragg Gratings Based on Phase Mask Interferometer}

\author{
Yoshinobu MAEDA, ${ }^{1,3}$ Koichi TANIMOTO, ${ }^{1}$ Tatsuya MATSUO,${ }^{1}$ Masakazu TAKAGI,${ }^{2}$ and Hideki NAKAYAMA ${ }^{3}$ \\ ${ }^{1}$ Department of Electric and Electronic Engineering, School of Science and Engineering, \\ Kinki University, 3-4-1 Kowakae, Higashi-Osaka, Osaka 577-8502 \\ ${ }^{2}$ Tatsuta Electric Wire \& Cable Co., Ltd., 3-17 Osadano, Fukuchiyama, Kyoto 620-0853 \\ ${ }^{3}$ Hikari-triode Co., Ltd., 2-10-41 Ohmido, Higashi-Osaka, Osaka 577-0817
}

(Received November 13, 2009)

\begin{abstract}
A negative feedback semiconductor optical amplifier was realized in an InGaAsP-InP amplifier using a fiber Bragg grating based on a phase mask interferometer. The gratings must possess such functions as the transmission of input light through a semiconductor optical amplifier and the reflection of the surrounding light emitted by optical amplification. Two gratings of slightly different center wavelengths were imprinted onto the fiber next to each other. The negative feedback effect recovers the signal loss to a higher definition and lower error probability. The optical amplifier with negative feedback provided an output signal whose gain and waveform was stabilized optically. A noise reduction effect was obtained at a central wavelength of the fiber Bragg grating.
\end{abstract}

Key Words: Fiber Bragg grating, Phase mask interferometer, Semiconductor optical amplifier, Crossgain modulation, Negative feedback optical amplification effect

\section{1. はじめに}

今日の光通信は，波長分割多重技術を利用して光ファ イバの全帯域を活用するフォトニックネットワークが構 築されようとしている。半導体光増幅器 (Semiconductor optical amplifier: SOA)は, 小型で量産性に優れるという メリットがあるが現状ではほとんど実用化されていな い. 実用化されていない要因としては, エルビウムなど の希土類元素を添加した光ファイバ増幅器に比べて偏波 依存性や雑音特性が劣るという問題がある。これまでに 我々は一端が反射タイプの半導体光増幅器 (Reflective Semiconductor Optical Amplifier: RSOA) における相互利得 変調 $(\mathrm{XGM})$ を2段用いたタンデム波長変換型の光トライ オード (Optical triode)を提案し，3端子の信号増幅作用 を有することを示してきた ${ }^{1,2)}$ 。また, RSOAのXGM ${ }^{3)} に$ おける消光比が向上する原因を究明した結果, SOAの雑 音抑制技術として負帰還光増幅効果 (Negative feedback optical amplification effect $)^{4)}$ を見出した. 本効果は, 入力 光信号に対してSOA内で発生した自然放出光をSOAに帰
還(フィードバック)させることによって実現する，この 自然放出光はSOAのXGMによって入力光信号の強度変 化に対して強度反転しており，SOA内部の利得を入力光 信号に応じて動的に変調し，エレクトロニクスの負帰還 増幅技術と同様な雑音抑制効果を得ている。

エレクトロニクスにおいては負帰還増幅技術が広く活 用されており，利得の安定や低雑音な電気信号増幅を可 能としている。エレクトロニクスでは電気的に正・負が 存在するため，負帰還増幅技術を実現することは容易な ことであるが，光信号には負の值が存在しないため種々 の工夫がなされている，SOAの利得安定化技術として， 信号バンド外で生成させたレージングモードを用いたゲ インクランプ $\mathrm{SOA}^{5)}$ が多くの研究機関で研究・開発され ている。他方，我々が提案した方法と同様なバンドパス フィルタを用いたフィードバックループ実験系で，ゲイ ンコントロール $\mathrm{SOA}^{6)}$ が報告されている。

本研究では，周囲光の帰還を実現するために特別に設 計した反射波長特性を有した光ファイバ型フィルタ (FBG：ファイバブラッググレーティング)を位相マスク 
干渉法で作製した。このFBGを搭載した光ファイバの先 端をレンズ化して，SOAと結合させて負帰還SOAを構成 した，本研究では入力信号のビット誤り率や雑音指数な どの波長依存性について測定し, その雑音抑制効果を示 す.

\section{FBGの作製と負帰還光増幅効果}

本研究で用いたファイバブラッググレーティング (FBG) は光ファイバ内に形成された回折格子である.ブ ラッグ回折格子には特定波長の光を反射する性質があ る. FBGは光の進行方向に屈折率の高い部分と低い部分 が交互に繰り返される屈折率変調型グレーティングであ り，グレーティング周期 $\Lambda$ と反射される波長 (ブラッグ 波長) $\lambda_{B}$ とは(1)式で関係づけられる。

$$
\lambda_{B}=2 n_{\text {eff }} \Lambda\left(n_{\text {eff }} \text { : 実効屈折率 }\right)
$$

光ファイバのコアには屈折率をクラッドより高めるため $\mathrm{GeO}_{2}$ が添加されている。 この $\mathrm{GeO}_{2}$ が $\mathrm{SiO}_{2}$ 中に酸素欠乏 欠陥を生じさせ $240 \mathrm{~nm}$ 近傍に吸収带を持つ。したがっ て240 nm近傍の紫外線を照射するとクラマース・クロ ニッヒの関係(光の吸収と屈折率の変化との関倸)により 屈折率が上昇すると説明されるが，あるいは紫外光照射 による分子再配列からガラス構造の圧縮が起こるともい われている7゙。また，あらかじめ高圧水素処理により紫 外光に対する感度を大幅に改善することができることも 報告されている ${ }^{8}$. この現象 (光誘起屈折率変化) を利用 して, ファイバコア内に屈折率変調を形成する。

代表的な作成方法が位相マスク法である。被覆を除去 したファイバの側方(円周方向)から位相マスクを介して 強い紫外線レーザービームを照射すると, レーザー光は 位相マスクにより回折光となり, ファイバコア上に干渉 縞が形成される。フファイ゙コア内にはこの干渉縞周期に 対応した屈折率変調が形成される。コア内のグレーティ ング周期 $\Lambda$ は位相マスクのグレーティング周期 $d$ の $1 / 2$ に なり，良好な再現性が得られる。位相マスク法の利点は 可干渉性(コヒーレンシ)の低いレーザービームでも使用 できることである. 他方, 二光束干渉露光法は再現性は 低いものの, 高額消耗品である位相マスクを必要とせ ず, 同一の光学系で幅広い波長対応が可能なことから, 多品種少量生産に適した手法といえる。ただし，グレー ティング周期を次第に変化させ，反射波長带域を広げる ようなチャープグレーティングの作製では干渉計にレン ズ系を組み込むなど，さらに調整の困難さが伴う．

本研究では, 位相マスク法の高い再現性と二光束干涉 露光法の広い対応波長域を兼ね備える製造手法である Fig. 1に示す位相マスク干渉法" を用いた。この手法では 位相マスクで回折される+/-一次光のみをミラーで折り 返し，その角度を調整することで干渉縞の周期を制御し ている，従って，高次回折光との干渉を抑制することが 可能であり，透過带域での損失低減を実現している，本 研究に抢けるファイバグレーティングフィルタに求めら れる機能は, SOAへ入力された入力光の波長は透過さ

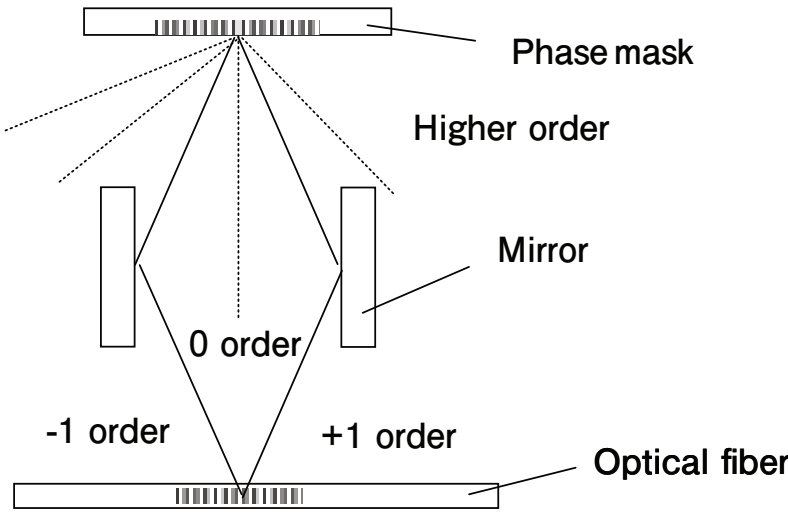

Fig. 1 Phase mask interferometer.

せ，増幅により発生した周囲光の一部をSOAに戻すこと である，そのためにFig. 2に示す透過打よび反射スペク トルをもつ反射率 $92 \%$ \%BGを作製した，周囲光はあ る一定の広がりをもち，ファイバグレーティングの反射 帯域にも広がりを持たせる必要がある。このため反射中 心波長のわずかに異なる二種類のチャープグレーティン グ(反射中心波長 $1548 \mathrm{~nm}$ と $1554 \mathrm{~nm}$ ) を光ファイバの近 接した二箇所へそれぞれ書き达んだ。このとき位相マス ク干渉法を用いることで, 中心波長の選択，制御やファ イバ書き込み位置の調整などが容易に実現された。さら に，従来目視に頼ることの多かった光ファイバの位置や ミラー角度を，独自の調整アルゴリズムと光学系のコン ピュータ制御によりFBG作製の高い安定性と再現性を実
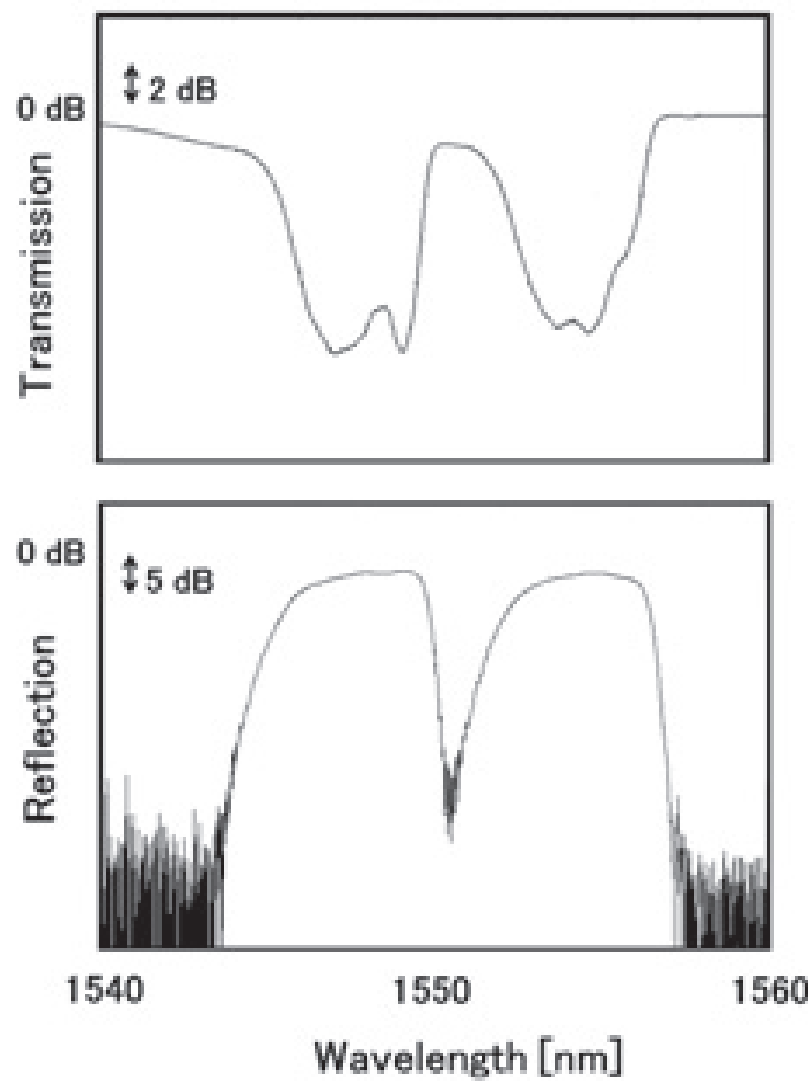

Fig. 2 Transmission and reflection spectrum of fiber Bragg grating for negative feedback optical amplifier. 
現した。試作したFBGの先端をレンズドファイバ化し， SOAの一端に結合して負帰還半導体光増幅器 (NF-SOA) を構成した

Fig. 3は，我々が提唱する負帰還光増幅効果の原理を 説明する概念図である。同図 (a) に示すように波長 $\lambda_{1}$ の 入力光がSOAに入射したとき, SOA内での相互利得変調 によって $\lambda_{1}$ の周囲波長 $\left(\lambda_{b}\right)$ の自然放出光が入力光に対し て逆位相に強度変調を受ける。 その強度変化の様子を同 図 (b)の実線で示している。この $P_{f}\left(\lambda_{b}\right)$ を負帰還光とし てSOAに帰還させると, SOA内部の相互利得変調により 波長 $\lambda_{1}$ に対する利得が同図 (c) の実線で示すように变調 される。 もし負帰還光 $P_{f}$ が無い場合は同図 $(\mathrm{c})$ の点線で 示したように，SOAの利得は一定である。利得が一定の 増幅器においては, 信号も雑音も同利得で増幅されるた め, 信号対雑音比 $(\mathrm{S} / \mathrm{N})$ を改善することは原理的に不可 能である。しかし, 負帰還光 $P_{f}$ がある場合は波長 $\lambda_{1}$ に対 する利得が同図(c)の実線に示すように変調される。こ のように動的に利得が変調されたSOAに同図 (a)に示す 入力光が入射された場合, 入力光強度が低いLowの場合 は利得が小さいため増幅度が低く, 出力光の0レベルは 負帰還光 $P_{f}$ がない場合より低下し，同図 (d)に示すよう に高い変調度(高い消光比)が得られて $\mathrm{S} / \mathrm{N}$ を改善するこ とが可能となる. Fig. 3は出力光の変調度の改善を定性

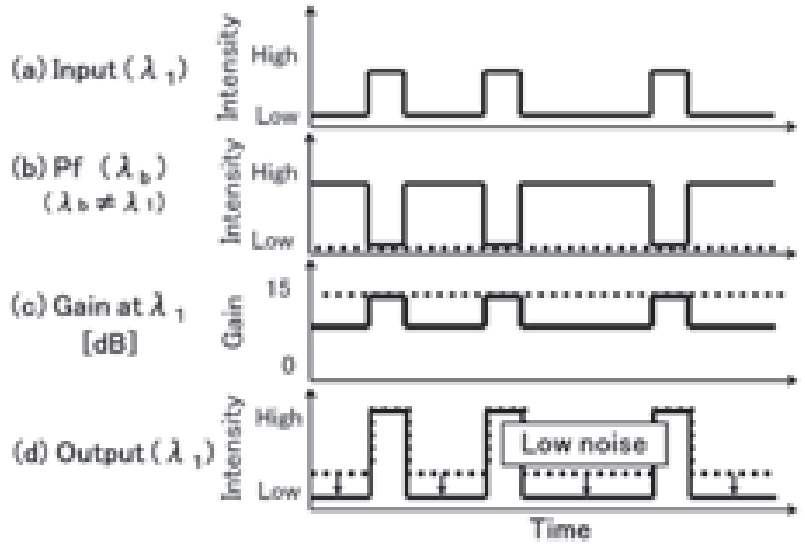

Fig. 3 Concept diagram of a negative feedback optical amplification effect. The straight-line represents the case where the SOA was used with negative feedback, and the dotted line represents the case of the SOA without negative feedback.

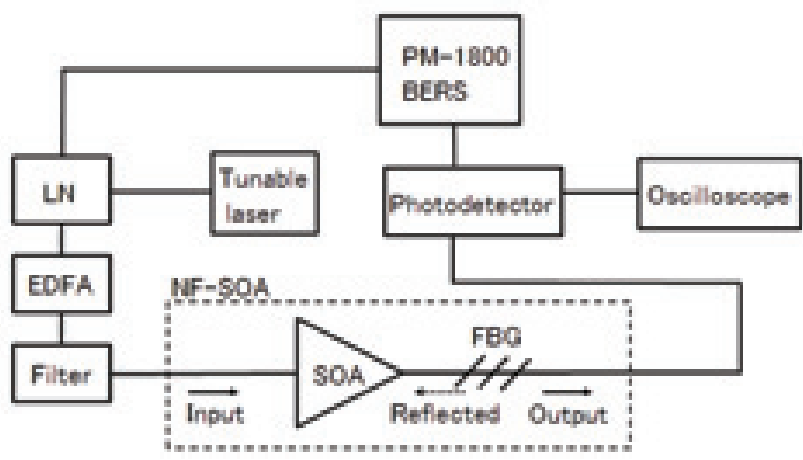

Fig. 4 Block diagram of the negative feedback semiconductor optical amplifier (NF-SOA) and measurement system.
的に示しただけであるが，前報出において，我々は出力 光の波形歪みの低減および変調度の改善が可能であるこ とを実験的に負帰還光増幅効果として示している。

\section{3. 測定結果}

Fig. 4はNF-SOAの構成図および測定系を示すＳOA は, InGaAsP-InPリッジタイプの半導体光増幅器を用い た。多重量子井戸で構成されたInGaAsPの活性層の中心 波長は約 $1500 \mathrm{~nm}$ であり, $250 \mathrm{~mA}$ の注入電流でファイバ 端の利得で約 $17 \mathrm{~dB}$ が得られた。Fig. 5 は, $1550 \mathrm{~nm}$ の入 力信号に対するゲイン飽和特性を示す. 出力光パワーで - 25 から $0 \mathrm{dBm}$ の範囲でゲインが一定で，飽和パワーは 約7 dBmであることがわかる. Fig. 6はSOAから放射され た自然放出光 (ASE) スペクトルを示す. 出力端にFig. 2 に示す特性のFBGを搭載しているために，1550 nm付近 でその特性が現われている。

測定系では波長可変レーザー光源から得られた種々の 波長のレーザー光をニオブ酸リチウム (LN) 光変調器で 強度変調し, Er添加光ファイバ増幅器 (EDFA) で信号増 幅した後にバンド幅 $1 \mathrm{~nm}$ の可変フィルタを透過させ, 可変光減衰器 $(\mathrm{VOA})$ で強度調整をして入力信号光とし た。負帰還光増幅効果により出力光の波形歪みの低減が 可能であることを実験的に検証するために，光通信で用

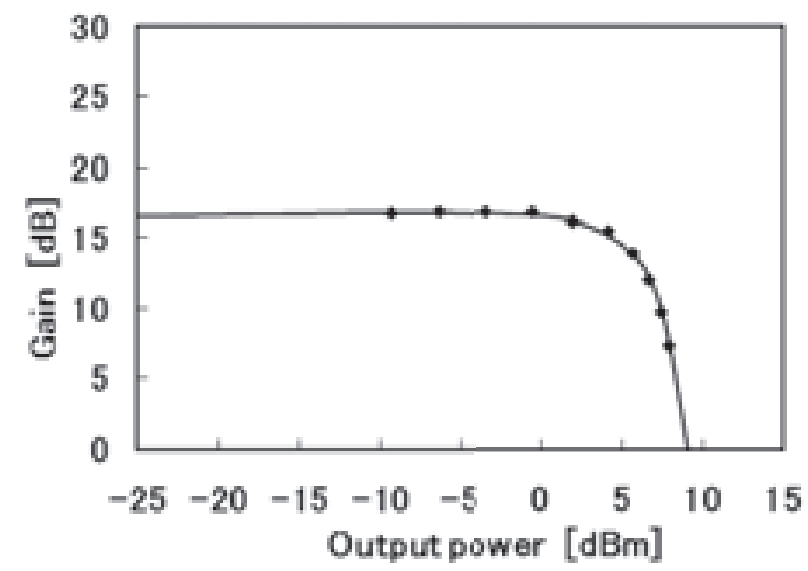

Fig. 5 Characteristic of saturation gain for NF-SOA.

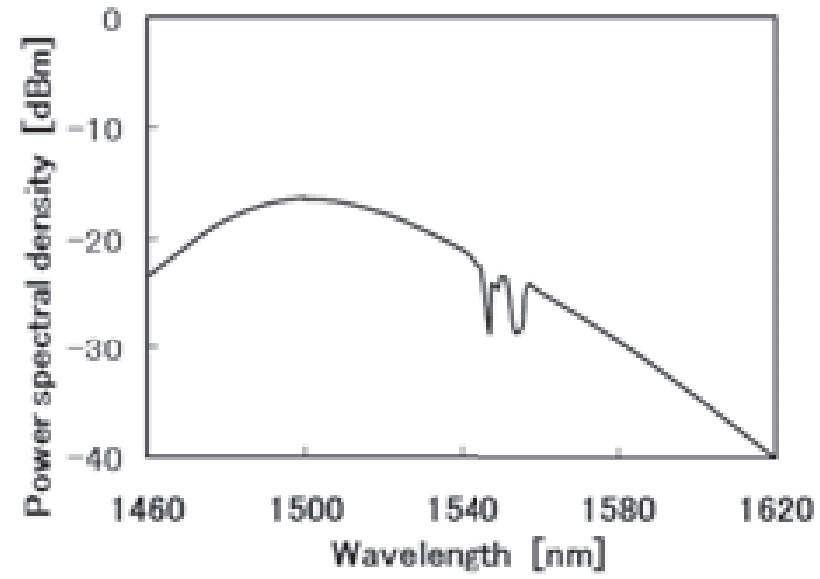

Fig. 6 ASE spectrum for NF-SOA. 
(a) $1530 \mathrm{~nm}$

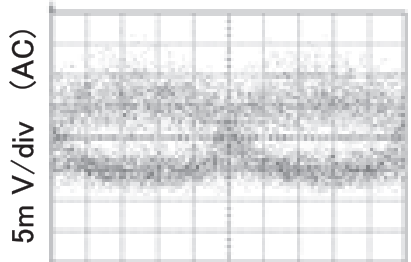

(c) $1550 \mathrm{~nm}$

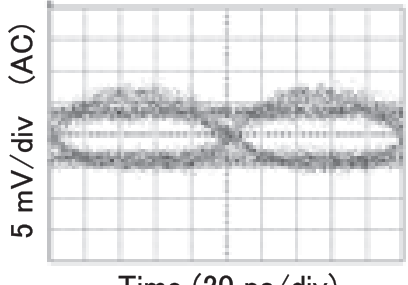

Time (20 ps/div) (b) $1544 \mathrm{~nm}$

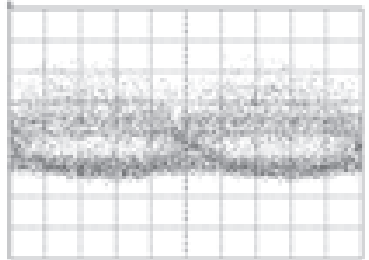

(d) $1558 \mathrm{~nm}$

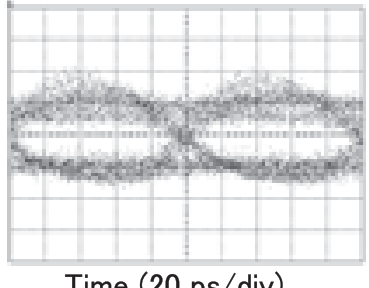

Time (20 ps/div)
Fig. 7 Eye-pattern waveforms of (a) 1530, (b) 1544, (c) 1550 and (d) $1558 \mathrm{~nm}$ for NF-SOA.

いられているランダムビットを伝送した場合のビット誤 り率 $(\mathrm{BER})$ の測定を行った。 BERの測定にはアンリツ製 のPM-1800シグナルクオリティアナライザ装置を用い た。 パターン発生器は, $10 \mathrm{Gbps}$ でNRZ $2^{31}-1$ 疑似ランダ ムビットシーケンスの連続信号を発生した。

Fig. 7 (a)，（b)，（c）および(d) は, NF-SOAに入力信 号 $(-7 \mathrm{dBm})$ のレーザー光の波長を $1530 ， 1544 ， 1550$ お よび $1558 \mathrm{~nm}$ に設定した場合，出力光をそれぞれオシロ スコープで観測したアイパターン波形を示す。同図より

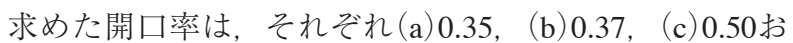

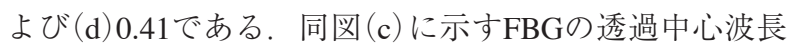
の1550 nm対する波形は，他の波形に比べて開口率が良 好なアイパターンが観測されている。 Fig. 8は, レー

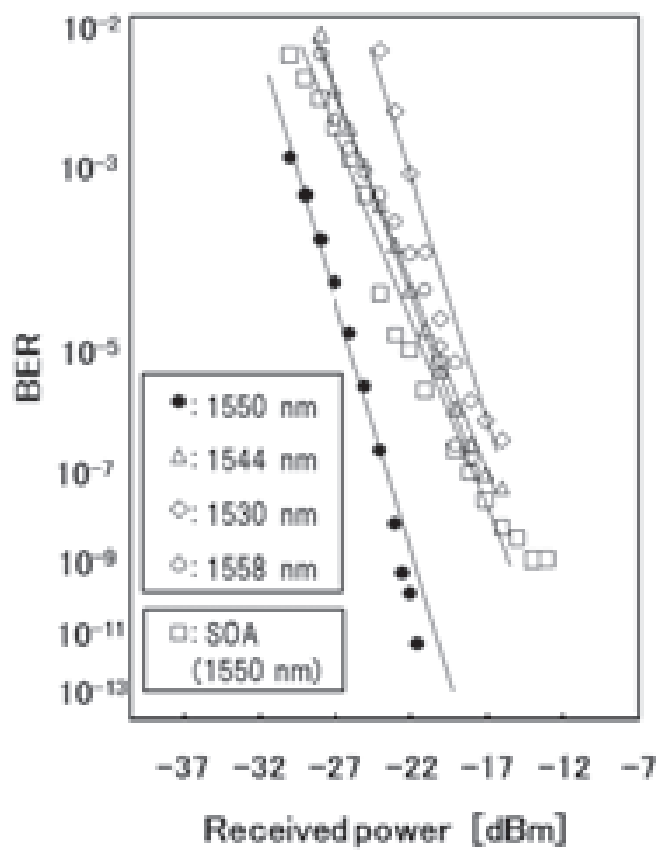

Fig. 8 Measured BER results for NF-SOA $1550 \mathrm{~nm}, \triangle: 1544 \mathrm{~nm}, \diamond: 1530 \mathrm{~nm}$, $1558 \mathrm{~nm})$ and $\mathrm{SOA}(\square: 1550 \mathrm{~nm})$.

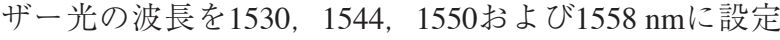
した場合のビット誤り率をNF-SOAに対して測定した結 果を示す $(\bigcirc: 1550 \mathrm{~nm}, \triangle: 1544 \mathrm{~nm}, \diamond: 1530 \mathrm{~nm}$, $\bigcirc: 1558 \mathrm{~nm}$ )。同図のBER曲線より，1550 nmを用いた 測定結果は，他波長の同じ受光パワーに比べて低いBER 值が観測され，パワーペナルティーが約 $1 \mathrm{~dB}$ 以上あるこ とがわかる。また，参照のために同図中に入力光信号の 波長を $1550 \mathrm{~nm}$ とした場合，通常のSOAに対するBERを 測定した結果を示す $(\square: 1550 \mathrm{~nm})$. 同図のBER曲線よ り，1550 nmとした場合のNF-SOAを用いた測定結果は， 通常のSOAの同じ受光パワーに比べて低いBER值が観測 されることがわかる。

NF-SOAおよび通常のSOAの諸特性をTable 1および2に それぞれ示す。 $G_{\max }$ および $G_{\text {min }}$ はそれぞれ利得の最大值 および最小值を示し，PDGおよびNFはそれぞれ偏光依 存性利得および雑音指数を示している.PDGは入力光信 号の偏光状態で決定される光増幅器の利得であり，一般 的に偏光依存性が小さい方が高性能な増幅器である. PDGはミューラー法で観測し，NFは光信号のSN比 (OSNR) から算出した. Table 1に示したNF-SOAの利得 はFBGによって自然放出光の一部が州還されている関係 で，Table 2に示した通常のSOAに比べて減少している.

一方, Table 1に示したNF-SOAの雑音指数NF值はTable 2 に示した通常のSOAの約 $9 \mathrm{~dB}$ に比べてそれぞれ低減 $(1530 \mathrm{~nm}: 8.3 \mathrm{~dB}, 1544 \mathrm{~nm}: 6.1 \mathrm{~dB}, 1558 \mathrm{~nm}: 6.2 \mathrm{~dB})$ され ていることがわかる。特に，FBGの透過中心波長の $1550 \mathrm{~nm}$ 対するNF值は5.1 dBと最小值を示しており，負 帰還光増幅効果による低雑音化を実現している。また， Table 1に示したNF-SOAのPDG值はTable 2に示した通常 のSOAに比べて各波長において $0.1 \mathrm{~dB}$ 程度減少してお り，偏光依存性の小さい良好な特性を示している。

Table 1 Specification of gain, PDF and NF for NF-SOA.

\begin{tabular}{ccccc}
\hline Wavelength & $\mathrm{G}_{\max }$ & $\mathrm{G}_{\min }$ & $\mathrm{PDG}$ & $\mathrm{NF}$ \\
\hline $1530 \mathrm{~nm}$ & $18.3 \mathrm{~dB}$ & $17.7 \mathrm{~dB}$ & $0.62 \mathrm{~dB}$ & $8.3 \mathrm{~dB}$ \\
\hline $1544 \mathrm{~nm}$ & $16.8 \mathrm{~dB}$ & $16.2 \mathrm{~dB}$ & $0.63 \mathrm{~dB}$ & $6.1 \mathrm{~dB}$ \\
\hline $1550 \mathrm{~nm}$ & $17.1 \mathrm{~dB}$ & $16.0 \mathrm{~dB}$ & $0.68 \mathrm{~dB}$ & $5.1 \mathrm{~dB}$ \\
\hline $1558 \mathrm{~nm}$ & $17.2 \mathrm{~dB}$ & $15.8 \mathrm{~dB}$ & $0.69 \mathrm{~dB}$ & $6.2 \mathrm{~dB}$ \\
\hline
\end{tabular}

Table 2 Specification of gain, PDF and NF for SOA.

\begin{tabular}{ccccc}
\hline Wavelength & $\mathrm{G}_{\max }$ & $\mathrm{G}_{\min }$ & PDG & $\mathrm{NF}$ \\
\hline $1530 \mathrm{~nm}$ & $24.8 \mathrm{~dB}$ & $24.1 \mathrm{~dB}$ & $0.78 \mathrm{~dB}$ & $9.3 \mathrm{~dB}$ \\
\hline $1544 \mathrm{~nm}$ & $22.9 \mathrm{~dB}$ & $22.7 \mathrm{~dB}$ & $0.70 \mathrm{~dB}$ & $8.9 \mathrm{~dB}$ \\
\hline $1550 \mathrm{~nm}$ & $22.0 \mathrm{~dB}$ & $21.5 \mathrm{~dB}$ & $0.75 \mathrm{~dB}$ & $9.0 \mathrm{~dB}$ \\
\hline $1558 \mathrm{~nm}$ & $20.9 \mathrm{~dB}$ & $20.1 \mathrm{~dB}$ & $0.76 \mathrm{~dB}$ & $9.1 \mathrm{~dB}$ \\
\hline
\end{tabular}

\section{4. 討 論}

光増幅器に正帰還を施せばレーザー発振現象が生じ る。エレクトロニクスでも同様に正帰還させた増幅器に おいては発振現象が生じ，発振器として種々の電子回路 に活用されている。一方，エレクトロニクスおいては増 
幅器に負帰還を施して, 利得の安定や低雑音な電気信号 増幅を可能としている. また, 元来不安定な半導体素子 を安定化して低雑音な電気信号増幅を可能としている。

つまり，電子回路おける負帰還増幅回路では帰還率を決 定する抵抗によって増幅度が決まり，温度依存性の大き い半導体トランジスタの増幅度には依存しないことが重 要な技術である。しかし, 光技術の分野では負帰還の光 増幅技術はほとんど活用されていないのが実情である。 光信号を用いた光エレクトロニクスが発展するためには 負帰還の光増幅技術が将来的に必要不可欠であると考え られる.また, 本研究においては半導体材料に比べて温 度依存性が小さいガラス材料を主成分とするFBGを用い て負帰還を実現している。このことは負帰還増幅の電子 回路と同様に, 原理的には半導体SOAに比べて温度依存 性が小さいFBGを使用することによって温度安定化に有 効であると考えられる。すなわち，不安定なSOAをパッ シブなFBGで制御して, 雑音指数などの光増幅特性を改 善できる点が優れている，今後これらの観点から詳細な 実験を行って証明する必要がある。

Table 1および2においてNF-SOAのPDG值が通常のSOA に比べて $0.1 \mathrm{~dB}$ 程度改善される理由を考察する. FBGに 偏光依存性がなければ, SOAに戻される光も偏光依存性 はないと考えられる。一方, 信号光はFBGの偏光無依存 性の影響を直接受けないが，負帰還増幅によりSOA全体 の利得に信号光の偏光依存性が与える影響が小さくなっ ているため, 全体としてPDGが下がったのではないかと 考えられる。しかし，まだ初期段階のデータであること から, さらにPDGに関するデー夕を蓄積して解明する必 要がある.

負帰還光増幅器の応答速度を検討する必要がある。な ぜなら，負帰還光増幅は信号光と帰還光が時間遅れなく 重畳されないと効果を発揮しないばかりか, 逆に悪影響 を及ぼす可能性を有しているからである.SOAの相互利 得変調の動作原理は, プローブ光に対する利得の信号光 による変調である. 信号光が入力される $(0$ レベルから 1 レベルへの変化) 状態では誘導放出が主要因である。一 方, 信号光が入力されない(1レベルから0レベルへの変 化)状態ではキャリア密度が自発的に元のレベルに回復 する現象が支配的になり, $100 \mathrm{ps}$ 程度以上の緩和過程の 影響を受ける。したがって, 相互利得変調を高速化する ためにはキャリア回復時間の高速化が不可欠である。本 研究では, FBGを用いて周囲光をSOAにフィードバック させることによって負帰還光増幅器を実現しているが, 入力光の信号と負帰還光の信号が時間的に重ならないと 効果が得られない.今回の試作においてはSOAとFBGの 間隔は $1 \mathrm{~mm}$ 以下であり，信号の90\%程度が重なると計 算すれば10 Gbps程度まで負帰還効果が得られることに なるが, 詳細に検討する必要がある。

本研究において, ビット誤り率や杂隹音指数の入力光信 号の波長依存性について検討する. Fig. 6に示したSOA のゲインには波長依存性が存在する。一方, FBGによっ て帰還される負帰還光の強度は自然放出光なので, 入力 信号の波長依存性はなくほぼ一定と考えられる。した
がって，信号光に対する負帰還光の強度が負帰還光増幅 効果の度合いを決定することから，ゲインの高い波長の 入力光信号を用いた場合，負帰還光増幅効果の影響が相 対的に小さくなると考えられる。例えば，本実験で $1530 \mathrm{~nm}$ の光信号を用いた場合, Fig. 6およびTable 1\&2 の特性からゲインが大きいので出力信号の強度は他波長 より強くなる。一方, FBGによって帚還される負帰還光 の強度はほぼ一定と考えられる。したがって, $1530 \mathrm{~nm}$ の入力光信号を用いた場合, 負帰還光増幅効果の影響が 他波長 $(1544 ， 1550,1558 \mathrm{~nm})$ に比べて小さくなり，雑 音の抑制効果が減少すると考えられる。すなわち, SOA のゲインが小さい $1550 お よ ひ ゙ 1558 \mathrm{~nm}$ の方がFBGによる 負帰還効果の影響を強く受けることにより，雑音の抑制 効果が大きいと考えられる。 さらに, FBGの中心波長で ある $1550 \mathrm{~nm}$ の方が $1558 \mathrm{~nm}$ に比べてビット誤り率およ びNF值が小さい理由は, FBGによって反射される光波 長の媒質中を伝搬する速度依存性が影響していることが 考えられる. 他方, 負帰還光をフィードバックさせるこ とによって低雑音化が可能となるが，フィードバックを かけない場合に比べて出力(増幅度)が低下することが懸 念される，そこでFBGの設計指針としては，負帰還効果 が十分に得られ且つ出力が大きく取れる要求を満たすこ とが応用的には重要となる。

以上のことから，本研究ではSOAの利得を入力信号に 応じて動的に変調することによって，負帰還光増幅が可 能であることを提案した，利得を動的に変調するのに SOAの相互利得変調を利用しており, SOA 内部から発生 する自然放出光を上手く活用している，さらに，SOAに FBGを搭載した光ファイバを付加するだけのシンプルな 構成で実現できることは工業的にも有益である。また, NF-SOAを活用することにより従来のSOAの問題点であ る偏波依存性と雑音特性を改善できることを示した。し たがって, 今後提案した負帰還光増幅器が多くの光エレ クトロニクス分野で使われることが予期され，光版の負 帰還増幅技術の一方法を提示した意義は大きいと考えら れる。

\section{5. まとめ}

位相マスク法の高い再現性と二光束干涉露光法の広い 対応波長域を兼ね備える製造手法である位相マスク干渉 法を用いて, 負帰還光増幅器用のファイバブラッググ レーティングを作製した，FBGに求められる機能は，半 導体光増幅器へ入力される入力光の波長を透過させると 同時に発生した周囲光の一部をSOAにフィードバックさ せることである。このため反射中心波長のわずかに異な る二種類のチャープグレーティングを光ファイバの近接 した二箇所へそれぞれ書き込んだ。このとき位相マスク 干渉法を用いることで, 中心波長の選択，制御やファイ バ書き込み位置の調整などが容易に実現された。試作し たFBGの先端をレンズドファイバ化し，SOAの一端に結 合して負帰還半導体光増幅器(NF-SOA)を構成した. $10 \mathrm{Gbps}$ の疑似ランダム信号を用いたビット誤り率の測 
定において，FBGの中心透過波長である $1550 \mathrm{~nm}$ 用い た場合，他波長に比べて開口率が良好なアイパターンを NF-SOAで観測した。また，BER曲線より，1550 nmを 用いた測定結果は，他波長に比べてビット誤り率を低く 抑制できることがわかった。ささらに，雑音指数が $5.1 \mathrm{~dB}$ に低減された。これらの実験結果から, FBGを用いた負 帰還半導体光増幅器によって光増幅の低雑音化が可能で あることを示した。

\section{謝 辞}

本研究は科学研究費補助金基盤研究 (C) (21560048)の 助成を受けたものである。

\section{参考文献}

1) Y. Maeda and L. Occhi: IEEE Photon. Technol. Lett. 15 (2003) 257.

2）前田 佳伸, 幸元 直樹：レーザー研究 33 (2005) 189 .

3) B. Glance, J. M. Wiesenfield, U. Koren, A. H. Gnauck, H. M. Presby, and A. Jourdan: Electron. Lett. 28 (1992) 1714.

4) Y. Maeda: Appl. Phys. Lett. 88 (2006) 101108.

5) M. Bachmann, P. Doussiere, J. Y. Emery, R. N'Go, F. Pommereau, L. Goldstein, G. Soulage, and A. Jourdan: Electron. Lett. 32 (1996) 2076

6) K. K. Qureshi, H. Y. Tam, C. Lu, and P. K. A. Wai: IEEE Photon Technol. Lett. 19 (2007) 1401.

7）水波徹：応用物理 67 (1998) 1029.

8) P. J. Lemaire, R. M. Atkins, V. Mizrahi, and W. A. Reed: Electron Lett. 29 (1993) 1191.

9) 前田佳伸, 岡嶋 亮輔, 高木 正和, 中山秀樹：レーザー研 究 37 (2009) 540. 